\title{
Area-selective atomic layer deposition of molybdenum oxide $\odot$ (c)
}

Cite as: J. Vac. Sci. Technol. A 38, 042406 (2020); https://doi.org/10.1116/6.0000219

Submitted: 28 March 2020 . Accepted: 19 May 2020. Published Online: 17 June 2020

(iD) Julie Nitsche Kvalvik, (iD) Jon Borgersen, (D) Per-Anders Hansen, and (iD Ola Nilsen

\section{COLLECTIONS}

Paper published as part of the special topic on Special Topic Collection on Area Selective Deposition

F This paper was selected as Featured

SCI This paper was selected as Scilight
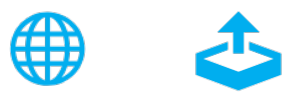

\section{ARTICLES YOU MAY BE INTERESTED IN}

Understanding chemical and physical mechanisms in atomic layer deposition

The Journal of Chemical Physics 152, 040902 (2020); https://doi.org/10.1063/1.5133390

Atomic layer deposition of metals: Precursors and film growth

Applied Physics Reviews 6, 041309 (2019); https://doi.org/10.1063/1.5087759

Conformality in atomic layer deposition: Current status overview of analysis and modelling Applied Physics Reviews 6, 021302 (2019); https://doi.org/10.1063/1.5060967

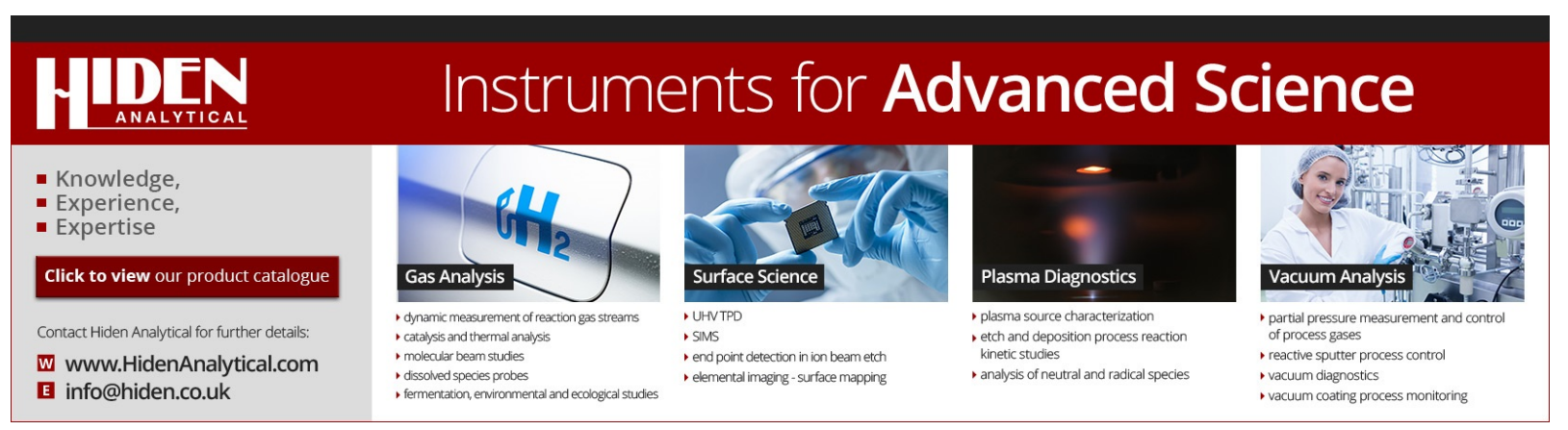




\title{
Area-selective atomic layer deposition of molybdenum oxide
}

\author{
Cite as: J. Vac. Sci. Technol. A 38, 042406 (2020); doi: $10.1116 / 6.0000219$ \\ Submitted: 28 March 2020 . Accepted: 19 May 2020 . \\ Published Online: 17 June 2020
}

${\text { Julie Nitsche Kvalvik, }{ }^{7} \text { (D) Jon Borgersen, }{ }^{2} \text { (D) Per-Anders Hansen, }{ }^{1} \text { (D) and Ola Nilsen }}^{7, a)}$ (iD

\begin{abstract}
AFFILIATIONS
${ }^{1}$ Centre for Materials Science and Nanotechnology, Department of Chemistry, University of Oslo, Postboks 1033, Blindern, O315 Oslo, Norway

${ }^{2}$ Centre for Materials Science and Nanotechnology, Department of Physics, University of Oslo, Postboks 1048, Blindern, 0315 Oslo, Norway
\end{abstract}

Note: This paper is a part of the Special Topic Collection on Area Selective Deposition.

${ }^{a)}$ Electronic mail: ola.nilsen@kjemi.uio.no

\begin{abstract}
Area-selective bottom-up synthesis routes of thin films are required to overcome the current limits in lithography, and such growth can be achieved with high quality and nanometer thickness control by area-selective atomic layer deposition (AS-ALD). However, the current range of materials demonstrated deposited by AS-ALD is limited, and no processes for molybdenum oxide have been available so far. In this work, the authors explore the properties of a new ALD precursor, $\mathrm{MoCl}_{4} \mathrm{O}$, for deposition of molybdenum oxides by $\mathrm{ALD}$. $\mathrm{MoCl}_{4} \mathrm{O}$ is administered at room temperature during deposition, making it readily available for use. When reacted with a combination of water and ozone, it leads to an AS-ALD process for deposition of $\mathrm{MoO}_{\mathrm{x}}$ - the first reported. The process is perfectly selective for growth on glass as compared to $\mathrm{Si}(100)$ substrates for deposition temperatures between 200 and $300{ }^{\circ} \mathrm{C}$, with a growth rate of $0.72 \AA /$ cycle at $300{ }^{\circ} \mathrm{C}$. The process is attempted on a range of substrates proving good growth on soda-lime glass and $\mathrm{LiF}$ and no growth on $\mathrm{Si}(100)$, silica, $\mathrm{Na}_{2} \mathrm{CO}_{3}$, $\mathrm{CaCO}_{3}, \mathrm{Li}_{3} \mathrm{PO}_{3}$, or $\mathrm{Li}_{2} \mathrm{SiO}_{3}$. The findings of this study indicate an activated process by diffusion of sodium or lithium through the film during growth. The obtained films have further been characterized by x-ray photoelectron spectroscopy, scanning electron microscopy, $\mathrm{x}$-ray diffraction, and atomic force microscopy, revealing films with an $\mathrm{RSM}$ roughness of $23 \mathrm{~nm}$ with the presence of crystalline $\mathrm{MoO}_{2}$ $(\mathrm{C} \mathrm{P} / \mathrm{m})$ when deposited at $300^{\circ} \mathrm{C}$ and crystalline $\mathrm{Mo}_{9} \mathrm{O}_{26}$ when deposited at $250^{\circ} \mathrm{C}$. The rough $\mathrm{MoO}_{\mathrm{x}}$ thin films may be applicable for electrocatalysis, gas sensors, or lithium-ion batteries. The findings of this study enable AS-ALD synthesis of molybdenum oxide with excellent selectivity not dependent on intermittent etching cycles during growth.
\end{abstract}

Published under license by AVS. https://doi.org/10.1116/6.0000219

\section{INTRODUCTION}

The semiconductor industry is currently approaching the limits of resolution in lithography-leaving a technology gap that may be filled with precise bottom-up synthesis approaches. ${ }^{1}$ One obvious choice to fill this gap is by atomic layer deposition (ALD), or more specifically, area-selective ALD (AS-ALD). ALD, in general, is known to give high quality films with supreme thickness control and conformity. AS-ALD will ease processing in comparison to conventional ALD, as fewer etching steps are required. Despite the fact that the concept has been around for 15 years, ${ }^{2}$ we have not seen a true boom in AS-ALD processes until now. ${ }^{3}$ This has yet to reach $\mathrm{MoO}_{3}$, which takes part in many applications also requiring precise manufacturing, such as catalysis, ${ }^{4-6}$ nanostructured gas sensors, ${ }^{7}$ injection layers in inverted organic photovoltaics, ${ }^{8}$ antibacterial coatings, ${ }^{9}$ electrochromic devices, ${ }^{10}$ and batteries, ${ }^{11}$ among others. For applications within electrocatalysis, ${ }^{12}$ gas sensors, ${ }^{13}$ or lithium-ion batteries, ${ }^{14}$ porous or rough $\mathrm{MoO}_{\mathrm{x}}$ films can be beneficial. A whole range of techniques has already been employed to deposit $\mathrm{MoO}_{3}$ thin films, although without area selectivity. This includes thermal evaporation, ${ }^{15} \mathrm{RF}$ sputtering, ${ }^{16}$ flash evaporation, ${ }^{17}$ metalorganic chemical vapor deposition, ${ }^{18}$ and $\mathrm{ALD},{ }^{19}$ which is the subject of this study.

The range of processes for deposition of $\mathrm{MoO}_{3}$ by ALD is limited, particularly for deposition at higher temperatures as the majority of molybdenum precursors decompose at $180^{\circ} \mathrm{C}$ or below. Deposition of $\mathrm{MoO}_{3}$ by ALD was first reported in 2010 (Ref. 19) using $\mathrm{Mo}(\mathrm{CO})_{6}$ as the Mo source together with $\mathrm{O}_{3}$ and $\mathrm{H}_{2} \mathrm{O}$ in the 
range of $152-172{ }^{\circ} \mathrm{C}$, after which the precursor decomposes. Si $\left(\mathrm{CH}_{3}\right)_{3} \mathrm{cpMo}(\mathrm{CO})_{2}\left(\mathrm{n}^{3}\right.$-2-methylallyl $)$ is in like manner reported to produce $\mathrm{MoO}_{3}$ together with $\mathrm{O}_{3}$ at $250-300^{\circ} \mathrm{C}{ }^{20}$ This process does, however, require an initial heating of the $\operatorname{Si}(100)$ substrate at $350{ }^{\circ} \mathrm{C}$ to prevent a nucleation delay of the following $\mathrm{MoO}_{\mathrm{x}}$ deposition. Another recent precursor for deposition of $\mathrm{MoO}_{3}$ is bis(ethylbenzene)Mo, which together with $\mathrm{H}_{2} \mathrm{O}$ shows ALD growth in the range of $135-150{ }^{\circ} \mathrm{C}^{21}$ Very recently, $\mathrm{MoO}_{2}\left(\mathrm{iPr}_{2} \mathrm{AMD}\right)_{2}$ (Ref. 22) has been demonstrated as a suitable precursor to form $\mathrm{MoO}_{3}$ up to its decomposition temperature of $175^{\circ} \mathrm{C}$ using $\mathrm{O}_{3}$ as the oxygen source. $\left(\mathrm{N}^{t} \mathrm{Bu}\right)_{2}\left(\mathrm{NMe}_{2}\right)_{2} \mathrm{Mo}$ was introduced as an alternative in 2015 and forms $\mathrm{MoO}_{3}$ with $\mathrm{O}_{3}$ in the temperature range of 100 $300{ }^{\circ} \mathrm{C}^{23}$ or $50-350{ }^{\circ} \mathrm{C}$ using plasma $\mathrm{O}_{2} .{ }^{24}$ The tungsten counterpart of $\left(\mathrm{N}^{\mathrm{t}} \mathrm{Bu}\right)_{2}\left(\mathrm{NMe}_{2}\right)_{2} \mathrm{Mo}$ has also been used as an ALD precursor ${ }^{25}$ to form $\mathrm{WO}_{3}$ with $\mathrm{H}_{2} \mathrm{O}$ as the coreactant and in combination with $\mathrm{La}$ (thd $)_{3}$ to form the proton-conducting ternary oxide $\mathrm{La}_{28-}{ }_{x} \mathrm{~W}_{4+x} \mathrm{O}_{54}$. The same work also mentions using $\mathrm{WCl}_{4} \mathrm{O}$ as a W source but was not pursued further as the $\mathrm{WCl}_{4} \mathrm{O}$ and $\mathrm{H}_{2} \mathrm{O}$ process seemed to stop after a few cycles and had a limited growth rate. Based on the similar chemistry of Mo and $\mathrm{W}$, we wanted to explore if this would also be the case for $\mathrm{MoCl}_{4} \mathrm{O}$ or if it would work as an ALD precursor. This is the topic of this work. With $\mathrm{MoCl}_{4} \mathrm{O}$, we are now able to expand the $\mathrm{MoO}_{\mathrm{x}}$ toolbox to include the $\mathrm{MoCl}_{4} \mathrm{O}+\left(\mathrm{H}_{2} \mathrm{O}+\mathrm{O}_{3}\right)$ process. However, to our surprise, this system exhibits clear signs of area-selective growth, as initial experiments revealed no film on $\mathrm{Si}(100)$ substrates, while glass substrates were clearly coated (Fig. 1).

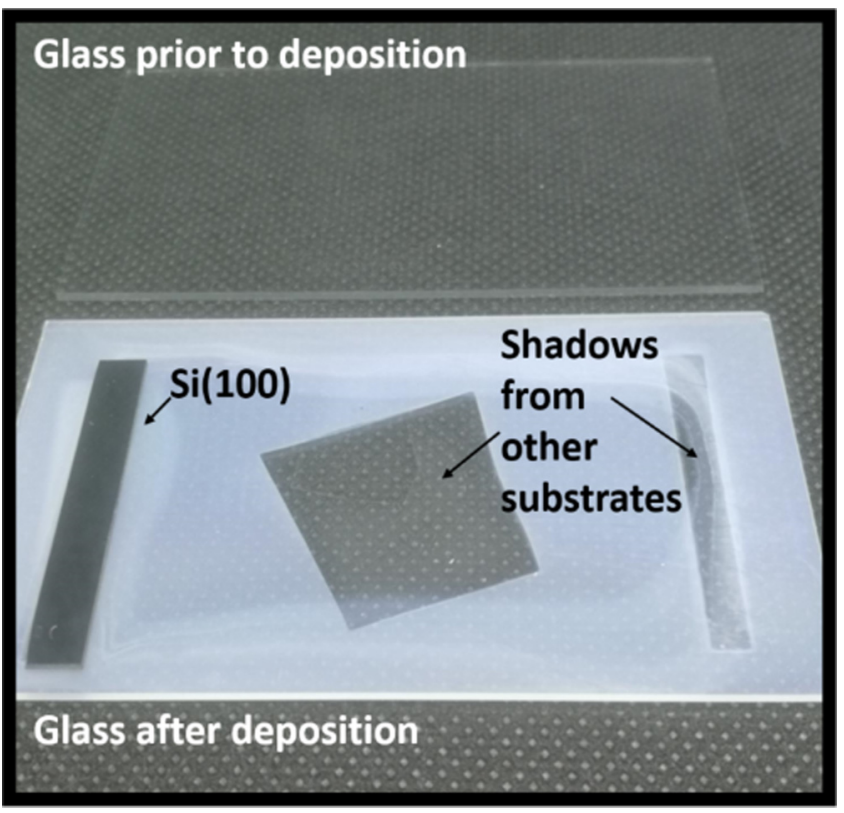

FIG. 1. Picture of an $\mathrm{MoO}_{x}$ thin film on glass and Si deposited at $300^{\circ} \mathrm{C}$ using 1000 cycles of $\mathrm{MoCl}_{4} \mathrm{O}$ and $\left(\mathrm{H}_{2} \mathrm{O}+\mathrm{O}_{3}\right)$. The film is clearly visible on the glass plate after deposition as compared to prior to deposition, but no film could be detected on the $\mathrm{Si}(100)$ strip.
Area-selective ALD is an emerging field particularly useful in semiconductor processing for electronics where numerous lithography steps are required. ${ }^{2,27}$ An overview of the field is given in Ref. 24 and can be summarized as divided into the following approaches: Inherent systems, where no extra measures are taken to make the system area-selective; the use of activators, using catalytic reactions on the surfaces, plasma enhanced areas, etc., such as for deposition of $\mathrm{Fe}_{2} \mathrm{O}_{3}$ and $\mathrm{NiO}$ by $\mathrm{O}_{2}$ gas with $t$-butyl ferrocene/ nickelocene on $\mathrm{Pt}$ and $\mathrm{Ir}$ substrates that dissociate $\mathrm{O}_{2}$, and not on the inert $\mathrm{SiO}_{2}, \mathrm{Al}_{2} \mathrm{O}_{3}$, and $\mathrm{Au}$ substrates; ${ }^{28}$ the use of inhibitors, such as for deposition of $\mathrm{SiO}_{2}$ on $\mathrm{GeO}_{2}, \mathrm{SiN}_{\mathrm{x}}, \mathrm{SiO}_{2}$, and $\mathrm{WO}_{3}$, and not on $\mathrm{Al}_{2} \mathrm{O}_{3}, \mathrm{TiO}_{2}$, and $\mathrm{HfO}_{2}$, ${ }^{29}$ where acetylacetonate chemoselectively inhibits growth by selective adsorption on the latter surfaces. Of these approaches, using inhibitors is by far the most used.

Other examples using inhibitors include the deposition of $\mathrm{TiO}_{2}$ on gold substrates using self-assembled monolayers (SAMs) as inhibitors, ${ }^{30} \mathrm{Ru}$ on $\mathrm{Cu}$ lines using amino-functionalized SAMs as inhibitors, ${ }^{31}$ and $\mathrm{CoO}$ on $\mathrm{SiO}_{2} / \mathrm{MgO}$ using polystyrene as inhibitors. ${ }^{32}$ The combination of atomic layer etching (ALE) and ALD is also employed to make thicker films only on the desired substrate. For example, $\mathrm{Al}_{2} \mathrm{O}_{3}$ has been deposited selectively on $\mathrm{Si}$ and not on octadecylphosphonic acid (OPDA)-SAM inhibited $\mathrm{Cu}$ with intermitting acid etch cycles. ${ }^{33}$

The figure of merit for quantification of the selectivity of a system is termed selectivity, $S$, and is in Ref. 24 defined as the amount (or rate) of one product relative to the total amount (or rate) of all products formed. $S$ also varies with the number of ALD cycles used and must therefore be reported together. ${ }^{27}$ An example of a reported selectivity is 2000:1 for Pt versus $\mathrm{SiO}_{2}$ substrates for the previously mentioned $\mathrm{Fe}_{2} \mathrm{O}_{3}$ system using 300 cycles. ${ }^{28}$

In this study, we further explore the effect of different types of substrates on the selectivity of the $\mathrm{MoCl}_{4} \mathrm{O}+\left(\mathrm{H}_{2} \mathrm{O}+\mathrm{O}_{3}\right)$ system to shed light on possible mechanisms behind our observations.

\section{EXPERIMENT}

\section{A. Atomic layer deposition}

All depositions were performed in an F-120 Sat reactor (ASM Microchemistry), in the temperature range of $200-350^{\circ} \mathrm{C}$. The purging gas was $\mathrm{N}_{2}$ at $300 \mathrm{~cm}^{3} \mathrm{~min}^{-1}$ from gas cylinders (Praxair, 99.999\%, further purified through a Mykrolis purifier) providing a background pressure of $\sim 4$ mbar. The depositions were carried out using $\mathrm{MoCl}_{4} \mathrm{O}$ (Sigma-Aldrich, 97\%) as the Mo source and distilled $\mathrm{H}_{2} \mathrm{O}$ and $\mathrm{O}_{3}$ pulsed simultaneously as the $\mathrm{O}$ source. $\mathrm{O}_{3}$ was supplied from an In USA ozone generator (AC-2505) at 15 wt. $\% \mathrm{O}_{3}$ in $\mathrm{O}_{2}$, using $\mathrm{O}_{2}$ from a gas cylinder (Praxair, 99.5\%). Both $\mathrm{MoCl}_{4} \mathrm{O}$ and $\mathrm{H}_{2} \mathrm{O}$ were kept at room temperature in external containers, and $\mathrm{MoCl}_{4} \mathrm{O}$ was assisted by $\mathrm{N}_{2}$ carrier gas. Standard pulsing times were $3 \mathrm{~s}$ for both $\mathrm{MoCl}_{4} \mathrm{O}$ and $\mathrm{O}_{3}+\mathrm{H}_{2} \mathrm{O}$, followed by $3 \mathrm{~s}$ purging after $\mathrm{MoCl}_{4} \mathrm{O}$ and $5 \mathrm{~s}$ after $\mathrm{O}_{3}+\mathrm{H}_{2} \mathrm{O}$, unless otherwise specified. The times were chosen based on experience with similar systems and gave here uniform films and reproducible data. A standard deposition consisted of 1000 cycles at a deposition temperature of $300{ }^{\circ} \mathrm{C}$. The $\mathrm{LiF}$ seeding layers were deposited using $\mathrm{LiO}^{t} \mathrm{Bu}$ (Sigma-Aldrich, 97\%) and $\mathrm{NH}_{4} \mathrm{~F}$ (Sigma-Aldrich, 99.99\%) based on an internally developed process. ${ }^{34}$ The $\mathrm{LiO}^{t} \mathrm{Bu}$ and $\mathrm{NH}_{4} \mathrm{~F}$ precursors were kept at 130 and $95^{\circ} \mathrm{C}$, respectively, and pulsed/purged with $5 / 5 \mathrm{~s}$ and $7 / 3 \mathrm{~s}$, respectively. 
A variety of substrates were used, including $\mathrm{Si}(100)$ with a native oxide layer, $\mathrm{Si}(100)$ with the following $\mathrm{ALD}$-deposited thin films- $\mathrm{CaCO}_{3}$ [from $\mathrm{Ca}$ (thd) $)_{2}, \mathrm{CO}_{2}$ and $\mathrm{O}_{3}$ (Ref. 35)], $\mathrm{Na}_{2} \mathrm{CO}_{3}$ [from $\mathrm{NaO}^{\mathrm{t}} \mathrm{Bu}, \mathrm{H}_{2} \mathrm{O}$, and $\mathrm{CO}_{2}$ (Ref. 36)], $\mathrm{Li}_{3} \mathrm{PO}_{3}$ [from $\mathrm{LiO}^{t} \mathrm{Bu}$, $\mathrm{Me}_{3} \mathrm{PO}_{3}$, and water, and $\mathrm{x}$-ray photoelectron spectroscopy (XPS) revealing a surface layer of $\mathrm{Li}_{2} \mathrm{CO}_{3}$ ], $\mathrm{LiF}$ and $\mathrm{Li}_{2} \mathrm{SiO}_{3}$ [from lithium trimethylsilanolate and $\mathrm{H}_{2} \mathrm{O}$ (Ref. 37)]-conventional soda-lime glass containing 15 mol. \% $\mathrm{Na}_{2} \mathrm{O}_{3}$ (Glaswarenfabrik Karl Heckt), and silica. $\mathrm{Si}(100)$, glass, and silica substrates were all washed with ethanol and blown dry prior to deposition. The other substrates were left untouched to not alter the films already deposited on them.

\section{B. Thin film characterization}

The thicknesses of the films were measured using a J. A. Woollam $\alpha$-SE spectroscopic ellipsometer in the range of 390$900 \mathrm{~nm}$, with the COMPLETEEASE software and Cauchy models to analyze the data. The models used two layers, one dense in the bottom and one rough on top, and took into consideration that $\mathrm{MoO}_{\mathrm{x}}$ is absorbing. For each sample, three spots were measured. It was spot dependent how easy it was to model the ellipsometry data, probably due to variations of the roughnesses of the films. Scanning electron microscopy (SEM) was performed using a HITACHI TM3000 SEM with a working distance of $\sim 9 \mathrm{~mm}$ and an acceleration voltage of $15 \mathrm{kV}$. A Quantax70 energy dispersive $\mathrm{x}$-ray spectrometer equipped with a silicon drift detector and $\mathrm{Cu}$ $\mathrm{Ka}$ radiation was used for elemental analysis. The acquisition time for each measurement was $5 \mathrm{~min}$. XPS measurements were carried out using a ThetaProbe instrument from ThermoScientific. The incident $\mathrm{x}$-ray beam was $\mathrm{Al} \mathrm{K} \alpha(1.487 \mathrm{keV})$ and $4 \mathrm{keV} \mathrm{Ar}^{+}$was used for sputtering. The $\mathrm{C} 1 \mathrm{~s}$ peak at $285 \mathrm{eV}$ stemming from carbon contamination was used as internal standard for fitting of the XPS spectra. X-ray diffraction (XRD) was performed to study the crystallinity of the samples, using a Bruker D8 Discovery Diffractometer, with $\mathrm{Cu} \mathrm{K} \alpha \mathrm{l}$ radiation and a $\mathrm{Ge}(111)$ monochromator in a traditional Bragg-Brentano setup. Atomic force microscopy (AFM) was performed using a Park Systems XE-70 AFM equipped with a PPP-CONTSCR cantilever in the contact mode. The AFM micrographs were processed with the GWYDDION software. Four-point probe inline resistivity measurements was performed using a Keithley 2400 SourceMeter.

\section{Lithography}

The LiF films were patterned using photolithography. A Microposit S1813 positive photoresist was applied using a spin coater, before the sample was baked at $120^{\circ} \mathrm{C}$ for $60 \mathrm{~s}$ on a hot plate. The pattern was exposed in a Heidelberg $\mu$ PG501 maskless lithography system and developed in the Microposit MF351 developer diluted with three parts de-ionized (DI) water. Following the development, the sample was rinsed for $1 \mathrm{~s}$ in DI water and immediately blown dry in $\mathrm{N}_{2}$ gas. The exposed LiF was etched by immersing the sample in DI water for $1 \mathrm{~min}$, before the photoresist was stripped by soaking in acetone for $4 \mathrm{~min}$. Unfortunately, $1 \mathrm{~min}$ of etching time was found to be excessive, and caused a loss of resolution in the pattern, however, still suitable to prove the possible use within lithography.

\section{Selectivity calculations}

The selectivity is calculated using the relation given in the Introduction, namely, that selectivity is the "the amount (or rate) of one product relative to the total amount (or rate) of all products formed." 27 This translates to the following equation where $S$ is the selectivity, $n$ is the number of cycles, and $\Theta_{1}$ is the measured fraction covered by nuclei at growth surface relative to the measured fraction at an adjacent nongrowth surface, $\Theta_{2}$. The full derivation of this is found in Ref. 27,

$$
S(n)=\frac{\Theta_{1}-\Theta_{2}}{\Theta_{1}+\Theta_{2}} .
$$

The measured fraction covered by nuclei is directly proportional to the deposited film volume. It is therefore possible to get a measure of this by various characterization methods such as spectroscopic ellipsometry, Auger electron spectroscopy, or electron dispersive $\mathrm{x}$-ray spectroscopy (EDS), which is used in this case. Here, the at. \% of Mo versus $(\mathrm{Si}+\mathrm{Mo})$ is used as $\theta$ for films deposited on both glass and $\mathrm{Si}(100)$ substrates.

\section{E. Thermodynamic calculations}

Thermodynamic calculations were performed using the HSC CHEMISTRY 8 software from Outotec.

\section{RESULTS AND DISCUSSION}

\section{A. $\mathrm{MoO}_{\mathrm{x}}$ thin film growth}

Using the standard pulsing and purging times, $\mathrm{MoO}_{\mathrm{x}}$ was successfully deposited by atomic layer deposition with similar growth rates on glass $(0.72 \AA /$ cycle $)$ and $\operatorname{LiF}(0.69 \AA /$ cycle $)$ substrates. It was possible to obtain a sufficient dose of $\mathrm{MoCl}_{4} \mathrm{O}$ kept at room temperature when extra carrier gas was flushed through the bubbler during pulsing. The films on glass appeared light blue. Based on this, glass was used as the standard substrate for subsequent investigations. A test for chemical vapor deposition growth was performed by pulsing only $\mathrm{MoCl}_{4} \mathrm{O}$ and keeping the reaction chamber at $300^{\circ} \mathrm{C}$. This resulted in no detectable film proving that the precursor does not decompose during operation. Initially, shorter pulsing and purging times (1s/ 1s/2s/3s) than the standard (3s/3s/3s/5s) mentioned in Sec. II. Experiments were tested, but this led to gradients with reduced growth along the flow direction in the reactor chamber. The standard pulsing and purging times were the shortest that also yielded even, reproducible films. No film was obtained using standard pulsing parameters on either $\mathrm{Li}_{2} \mathrm{SiO}_{3}, \mathrm{Si}(100)$ with a native oxide layer, $\mathrm{CaCO}_{3}, \mathrm{Na}_{2} \mathrm{CO}_{3}, \mathrm{Li}_{3} \mathrm{PO}_{3}$, or silica substrates, as measured with spectroscopic ellipsometry. See the supplementary material $^{50}$ for the measured thicknesses before and after deposition.

The growth per cycle of $\mathrm{MoO}_{\mathrm{x}}$ versus deposition temperature as grown on glass substrates is shown in Fig. 2. For 1000 cycles, the growth per cycle rapidly increases when the deposition temperature is increased from 275 to $300^{\circ} \mathrm{C}$, indicating a kinetically limited growth at temperatures below $300^{\circ} \mathrm{C}$. For 5000 cycles, there is a slight increase, although still within the error margin, between 300 and $350{ }^{\circ} \mathrm{C}$. 


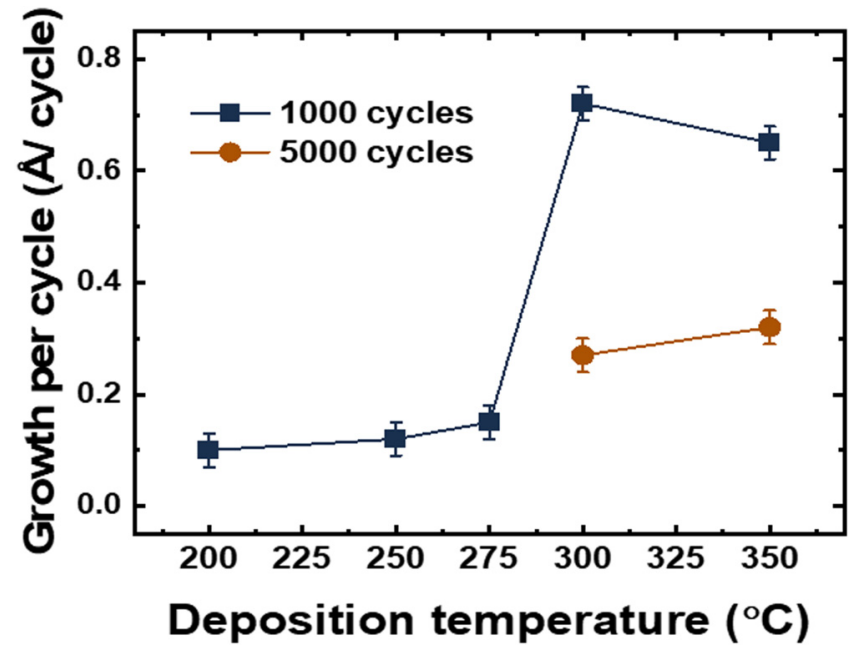

FIG. 2. Growth per cycle on glass vs deposition temperature of $\mathrm{MoO}_{\mathrm{x}}$ for the $\mathrm{MoCl}_{4} \mathrm{O} /\left(\mathrm{O}_{3}+\mathrm{H}_{2} \mathrm{O}\right)$ system using 1000 (squares) or 5000 (circles) ALD cycles. The uncertainties are estimated from the variance in data obtained for 1000 cycles at $300^{\circ} \mathrm{C}$ for three separate experiments.

The linearity with respect to the number of ALD cycles was investigated at $300^{\circ} \mathrm{C}$ (Fig. 3) proving an overall reduction in growth per cycle with increased film thicknesses. ALD processes are usually regarded as linear with the number of deposition cycles, unless nucleation or evolution of texture affects the available surface area. The current observation with temperature and thickness dependent

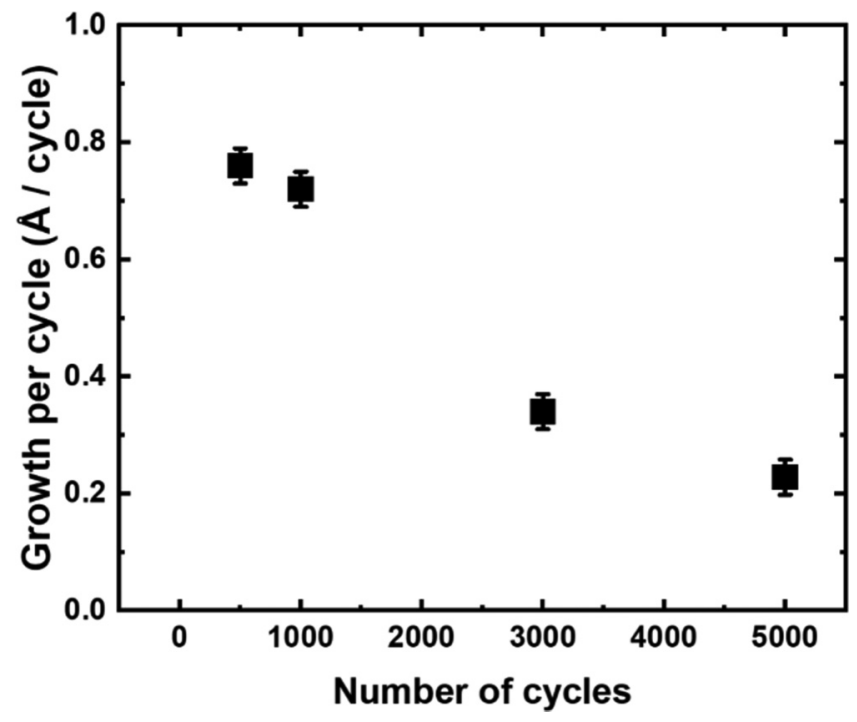

FIG. 3. Growth per cycle of $\mathrm{MoO}_{x}$ vs number of cycles for the $\mathrm{MoCl}_{4} \mathrm{O}$ / $\left(\mathrm{O}_{3}+\mathrm{H}_{2} \mathrm{O}\right)$ at $300^{\circ} \mathrm{C}$. The uncertainties are estimated from the variance in data obtained for 1000 cycles at $300^{\circ} \mathrm{C}$ for three separate experiments.
TABLE I. Growth rate of $\mathrm{MoO}_{x}$ on glass using $\mathrm{MoOCl}_{4}$ and a selection of oxygen sources at a substrate temperature of $300{ }^{\circ} \mathrm{C}$ and 1000 cycles, as measured with spectroscopic ellipsometry.

\begin{tabular}{lc}
\hline \hline $\mathrm{O}$ source & Growth per cycle $(\AA)$ \\
\hline $\mathrm{O}_{3}+\mathrm{H}_{2} \mathrm{O}$ pulsed simultaneously & 0.72 \\
$\mathrm{Only}_{3}$ & 0.12 \\
Only $\mathrm{H}_{2} \mathrm{O}$ & 0.10 \\
\hline \hline
\end{tabular}

growth indicates that the process may be controlled by diffusion of an active component from the substrate itself. This also explains why the growth per cycle increases between 300 and $350{ }^{\circ} \mathrm{C}$ for 5000 cycles, as the growth of thicker films is more limited by diffusion, which is in turn enhanced at higher temperatures. See the supplementary material ${ }^{50}$ for attempts on modeling the evolution in film thickness based on diffusion limited principles.

As this system exhibits clear selectivity with respect to the substrate material, further investigations were performed to gain more insight into its origin. A first step was investigating the oxygen source, if both $\mathrm{O}_{3}$ and $\mathrm{H}_{2} \mathrm{O}$ play an active part in the growth. When changing the oxygen source to only $\mathrm{H}_{2} \mathrm{O}$ or $\mathrm{O}_{3}$, a clear reduction of the overall growth rates was observed (Table I). A similar dependency is previously reported for when $\mathrm{Mo}(\mathrm{CO})_{6}$ is used as an Mo source, although at a reduced magnitude. ${ }^{19}$ For the $\mathrm{Mo}(\mathrm{CO})_{6}$ process, the effects of omitting $\mathrm{H}_{2} \mathrm{O}$ was negligible, but a reduction in growth rate of about $75 \%$ was observed when omitting $\mathrm{O}_{3}$.

XRD analysis of the films shows a strong dependency of the crystallinity with deposition temperature (Fig. 4). Films deposited at $250{ }^{\circ} \mathrm{C}$ match well with $\mathrm{Mo}_{9} \mathrm{O}_{26}(\mathrm{P} 2 / \mathrm{C})$, while the crystallinity is reduced at $275^{\circ} \mathrm{C}$, and at $300^{\circ} \mathrm{C}$, there is only one clear peak present, and this matches well with $\mathrm{MoO}_{2}$ (C 2/m, tugarinovite). $\mathrm{Mo}_{9} \mathrm{O}_{26}$ is a Magnéli phase with a structure closely related to the

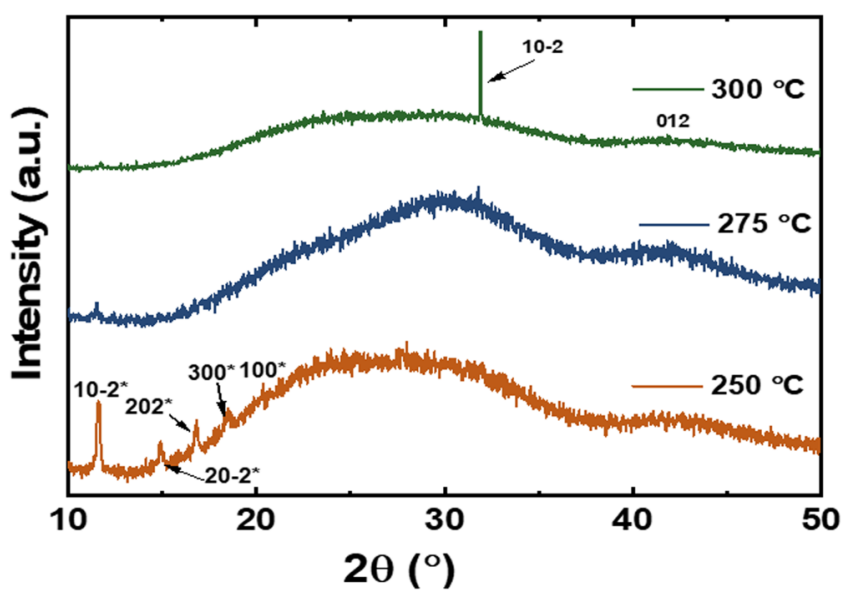

FIG. 4. XRD diffractograms of molybdenum oxide thin films deposited at varying temperatures using 1000 cycles. Selected reflexes from $\mathrm{Mog}_{9} \mathrm{O}_{26}(\mathrm{P} 2 / \mathrm{C}$, with asterisk) (Ref. 42) and $\mathrm{MoO}_{2}$ (C 2/m, tugarinovite, no asterisk) (Ref. 43) are indexed for comparison. 
more common layered $\alpha-\mathrm{MoO}_{3},{ }^{38}$ which consists of zig-zag layers of distorted $\mathrm{MoO}_{6}$ octahedra. ${ }^{39}$ This is similar for $\mathrm{Mo}_{9} \mathrm{O}_{26}$, but this structure also includes crystallographic shear planes as described by Magnéli. The crystallographic shear planes reduce the overall oxidation state for Mo from +6 in $\alpha-\mathrm{MoO}_{3}$ to approximately +5.8 in $\mathrm{Mo}_{9} \mathrm{O}_{26}$ without introducing oxygen vacancies. A previous study from our group, using the $\mathrm{Mo}(\mathrm{CO})_{6}+\left(\mathrm{O}_{3}+\mathrm{H}_{2} \mathrm{O}\right)$ process, showed that the films were amorphous as deposited at $167^{\circ} \mathrm{C}$, but crystallized to the metastable $\beta-\mathrm{MoO}_{3}$ when annealed at $400^{\circ} \mathrm{C}$ for $8 \mathrm{~min}$ and as $\alpha-\mathrm{MoO}_{3}$ when annealed at $600{ }^{\circ} \mathrm{C}$ for $8 \mathrm{~min} .{ }^{40}$ Another very recent study on $\mathrm{MoO}_{3}$ from our group identifies the crystallization process as both time and temperature dependent proving crystallization of $\beta-\mathrm{MoO}_{3}$ at only $185^{\circ} \mathrm{C}$ when annealed for an extended amount of time $(24 \mathrm{~h}){ }^{41}$ The formation of $\mathrm{MoO}_{2}$ is further discussed later in the text.

The microstructure of thin films deposited on glass substrates was investigated with SEM and AFM (Fig. 5). The microstructure
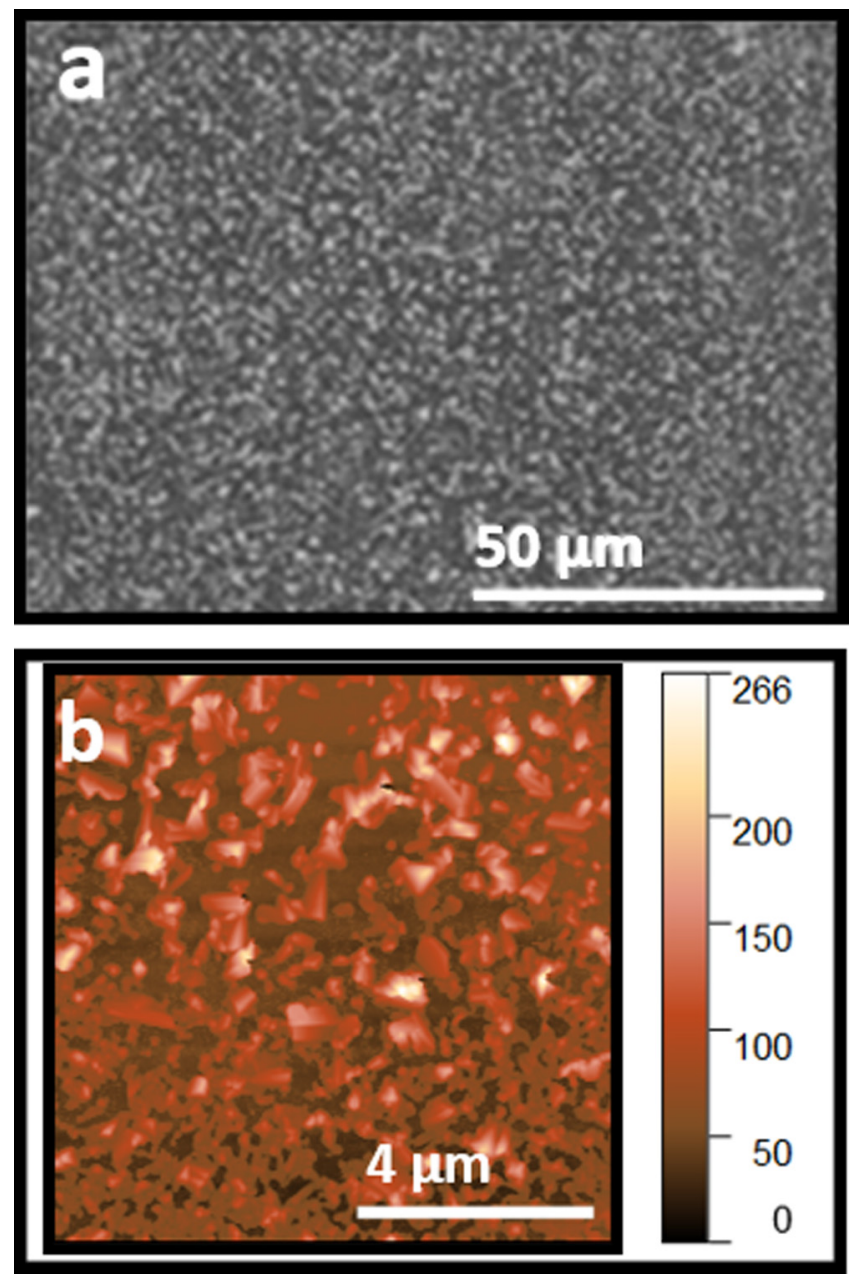

FIG. 5. SEM micrograph (a) of $\mathrm{MoO}_{x}$ deposited on glass at $250^{\circ} \mathrm{C}$ and AFM micrograph (b) of $\mathrm{MoO}_{x}$ deposited on glass at $300^{\circ} \mathrm{C}$ using 1000 cycles. was similar for all investigated deposition temperatures $\left(200-350^{\circ} \mathrm{C}\right)$, and the micrographs in Fig. 5 are thus representative for all the investigated samples. The topography appears rough and shows some signs of pinholes. The AFM micrograph further shows that some areas are denser with a thickness around $72 \mathrm{~nm}$, but some areas again have taller grains and more pinholes. The occurrence of pinholes reduces slightly with higher deposition temperatures, but the topography remains rough. The RMS roughness is $23 \mathrm{~nm}$ as estimated from the AFM micrograph for a film with total thickness of $72 \mathrm{~nm}$. To shed more light on the film quality, a four-point probe inline resistivity measurement was performed on a $114 \mathrm{~nm}$ thick film deposited at $300^{\circ} \mathrm{C}$. The film was insulating at room temperature, i.e., the sheet resistance was above $100 \mathrm{M} \Omega / \mathrm{sq}$.

XPS was performed on selected samples to investigate the state of molybdenum and to reveal the presence of any impurities that may be embedded in the growth process. The survey spectrum for a sample deposited at $300^{\circ} \mathrm{C}$ on glass is shown in Fig. 6. This shows that beside the expected peaks from oxygen and molybdenum, a large amount of sodium is also found in the films. The $\mathrm{Cl}$ $\mathrm{p}_{3 / 2}$ peak, which is the peak primarily used for analysis of chlorine by XPS, is normally found around $200 \mathrm{eV}$ and is absent in the spectrum below.

Two XPS scans were performed on two different spots of a sample deposited at $300^{\circ} \mathrm{C}$ to investigate the oxidation state of Mo (Fig. 7). For the Mo $3 \mathrm{~d}_{3 / 2}$ peak, the peak positions are at 236.1 and $235.4 \mathrm{eV}$ for the two scans, both within the expected range for the valance being $+6{ }^{44}$ The same goes for the Mo $3 \mathrm{~d}_{5 / 2}$ where the peak positions are at 232.8 and $232.1 \mathrm{eV}$. The observed shift for both Mo $3 \mathrm{~d}$ peaks between the two scans is less than expected if the valance indeed was different in the two spots.

A depth profile was also obtained by XPS on a $\mathrm{MoO}_{\mathrm{x}}$ film deposited on glass at $300{ }^{\circ} \mathrm{C}$, as shown in Fig. 8. It shows a relatively homogeneous distribution of sodium ions throughout the film, probably due to extended diffusion through the 2-h cooling process after the deposition. It should be kept in mind that the

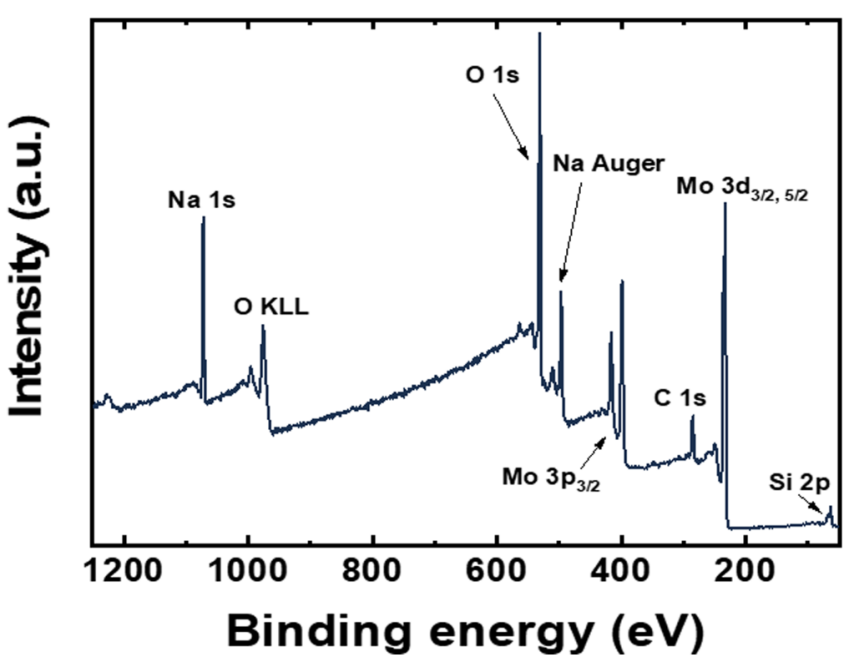

FIG. 6. XPS survey scan of $\mathrm{MoO}_{\mathrm{x}}$ thin film deposited at $300^{\circ} \mathrm{C}$ on glass 


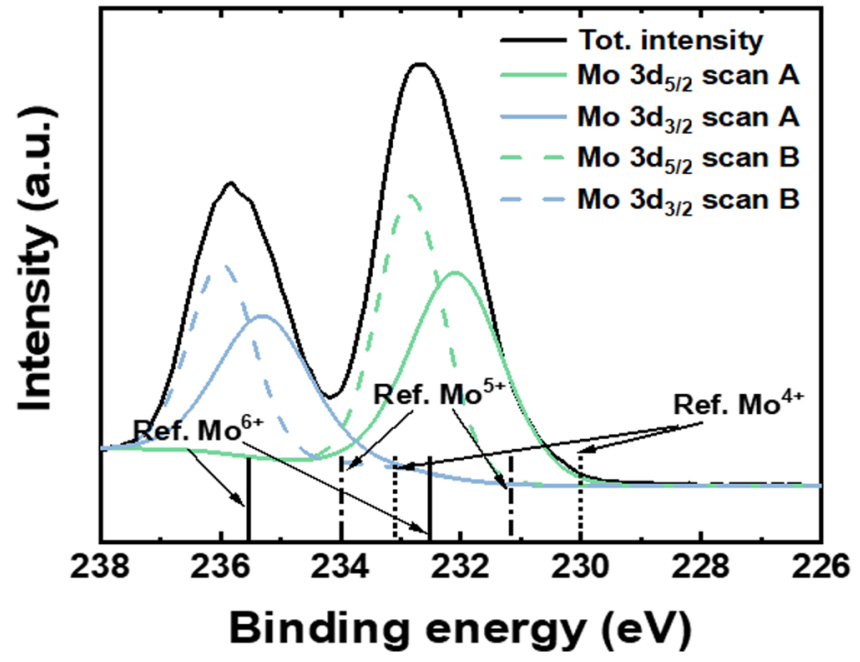

FIG. 7. XPS scans of Mo $3 \mathrm{~d}$ peaks to identify the oxidation state of molybdenum in an $\mathrm{MoO}_{x}$ thin film deposited at $300^{\circ} \mathrm{C}$ on glass. Two scans, $\mathrm{A}$ and $\mathrm{B}$, were performed at two different spots on the same sample during the same session. Expected peak positions for $\mathrm{Mo}^{6+}, \mathrm{Mo}^{5+}$, and $\mathrm{Mo}^{4+}$ from Ref. 44 are included for comparison.

argon sputtering during depth profiling can also affect the distribution of sodium throughout the film. We do observe an accumulation of sodium at the surface of the film with $6.6 \% \mathrm{Na}$ at zero etch time.

Experiments with prolonged purging times were performed to investigate how diffusion of sodium ions affect the growth rates of the $\mathrm{MoO}_{\mathrm{x}}$ thin film. If the growth is dependent on diffusion of

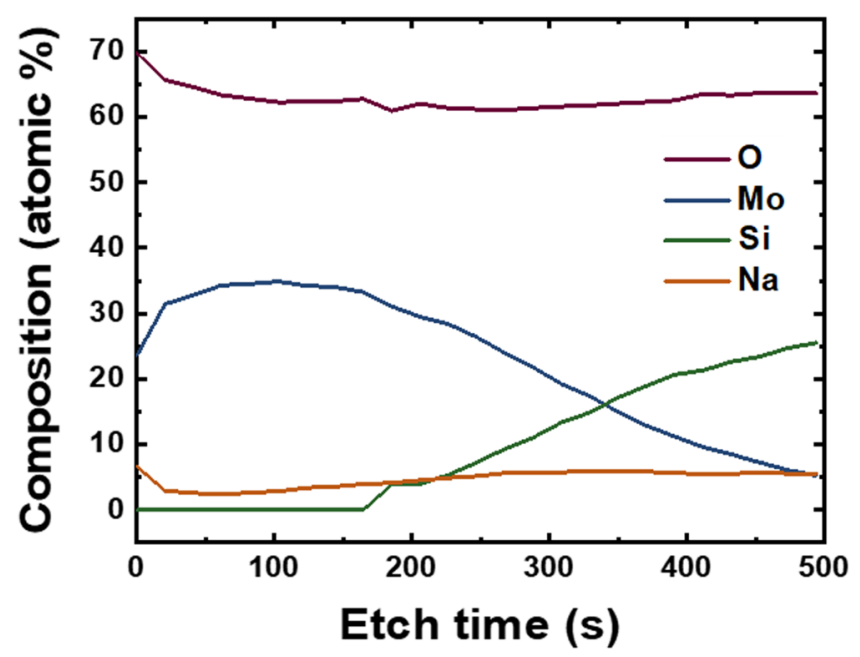

FIG. 8. XPS depth profile of $\mathrm{MoO}_{x}$ thin film as deposited at $300^{\circ} \mathrm{C}$ on glass.
TABLE II. Growth rate of $\mathrm{MoCl}_{4} \mathrm{O} /\left(\mathrm{O}_{3}+\mathrm{H}_{2} \mathrm{O}\right)$ on glass as a function of purging times at a substrate temperature of $300^{\circ} \mathrm{C}$ as measured with spectroscopic ellipsometry.

\begin{tabular}{lccc}
\hline \hline $\begin{array}{l}\text { Purging time } \\
\text { after } \mathrm{MoCl}_{4} \mathrm{O} \\
\text { pulse }(\mathrm{s})\end{array}$ & $\begin{array}{c}\text { Purging time } \\
\text { after } \mathrm{O}_{3}+\mathrm{H}_{2} \mathrm{O} \\
\text { pulse }(\mathrm{s})\end{array}$ & $\begin{array}{c}\text { Total cycle } \\
\text { time }(\mathrm{s})\end{array}$ & $\begin{array}{c}\text { Growth per } \\
\text { cycle }(\AA)\end{array}$ \\
\hline 3 & 5 & 14 & 0.72 \\
6 & 10 & 22 & 0.83 \\
9 & 15 & 30 & 1.15 \\
\hline \hline
\end{tabular}

sodium through the film, the growth rate should be affected by the purging times, leading to increased growth for longer purges, as this allows for more time for diffusion controlled processes. ${ }^{45}$ The results of such an investigation is shown in Table II and support our hypothesis, although with a higher dependency on the purging times than anticipated from Fick's laws of diffusion.

\section{B. Area-selective growth}

EDS measurements were performed on a number of samples deposited at various temperatures to quantify the selectivity of the process as a function of deposition temperature. Both growth (glass) and nongrowth $[\mathrm{Si}(100)]$ surfaces were investigated. As no molybdenum could be detected at the $\mathrm{Si}(100)$ surface for depositions at $300^{\circ} \mathrm{C}$ or below, the selectivity is here reported as perfect selectivity, i.e., 1 . For the film deposited at $350^{\circ} \mathrm{C}$, the selectivity was calculated from the EDS measurements to be 0.85 for glass over $\mathrm{Si}(100)$. See the supplementary material ${ }^{50}$ for details about this calculation.

To illustrate the selectivity of the system further, a pattern was produced by lithography on a $45 \mathrm{~nm}$ thick LiF film made by ALD on $\mathrm{Si}(100)$. Thus, both growth and nongrowth areas were present on the same substrate. A standard $\mathrm{MoO}_{\mathrm{x}}$ deposition was then performed on top of this patterned surface. An SEM micrograph of the resulting sample is shown in Fig. 9 where the brighter areas correspond to deposition of $\mathrm{MoO}_{\mathrm{x}}$. We found it challenging to perform good lithography on $\mathrm{LiF}$ due to its high solubility in water. Yet, samples with clear patterns were obtained.

To further illuminate the selectivity of the $\mathrm{MoCl}_{4} \mathrm{O}+\left(\mathrm{H}_{2} \mathrm{O}+\mathrm{O}_{3}\right)$ system, EDS mapping was performed on an $\mathrm{MoO}_{\mathrm{x}}$ film deposited on patterned $\mathrm{LiF}$ on $\mathrm{Si}(100)$ (Fig. 10). Both molybdenum and fluorine are present within the desired pattern in significant amounts. Attempts to quantify the concentration of molybdenum outside this pattern result in only 0.02 at. \%, whereas it revolves around 8 at. \% in the pattern itself. The reported values must not be considered absolute concentrations since the EDS analysis volume penetrates through the film and into the substrate. However, they do prove a selectivity for $\mathrm{MoO}_{\mathrm{x}}$ growth of around 400 times higher growth on the LiF pattern than in the surrounding area, even with imperfect patterning.

\section{Discussion}

We have here reported using the oxychloride $\mathrm{MoCl}_{4} \mathrm{O}$ for deposition of $\mathrm{MoO}_{\mathrm{x}}$ by atomic layer deposition. Equation (2) shows 


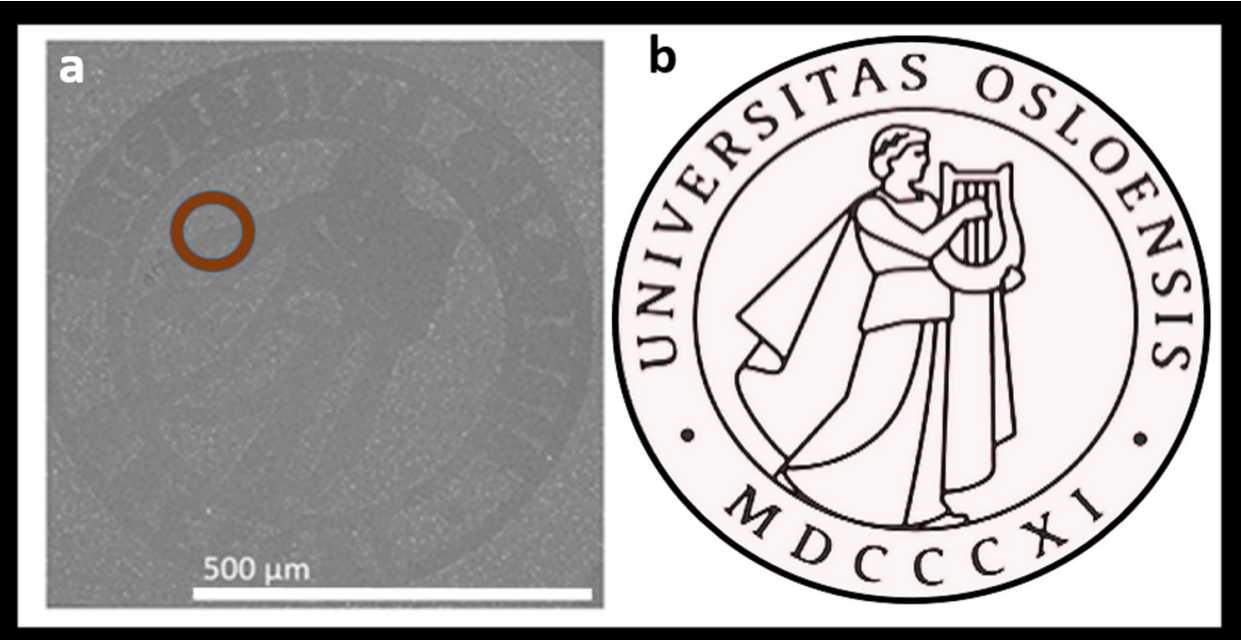

FIG. 9. SEM micrograph (a, left) illustrating the selectivity of the $\mathrm{MoO}_{\mathrm{x}}$ system as deposited on LiF. The pattern is the University of Oslo's logo (b, right). The LiF film under the lines of the logo shown in (b) was removed with lithography prior to deposition of $\mathrm{MoO}_{\mathrm{x}}$. The circle in the micrograph is the area where the EDS measurements in Fig. 10 are taken.
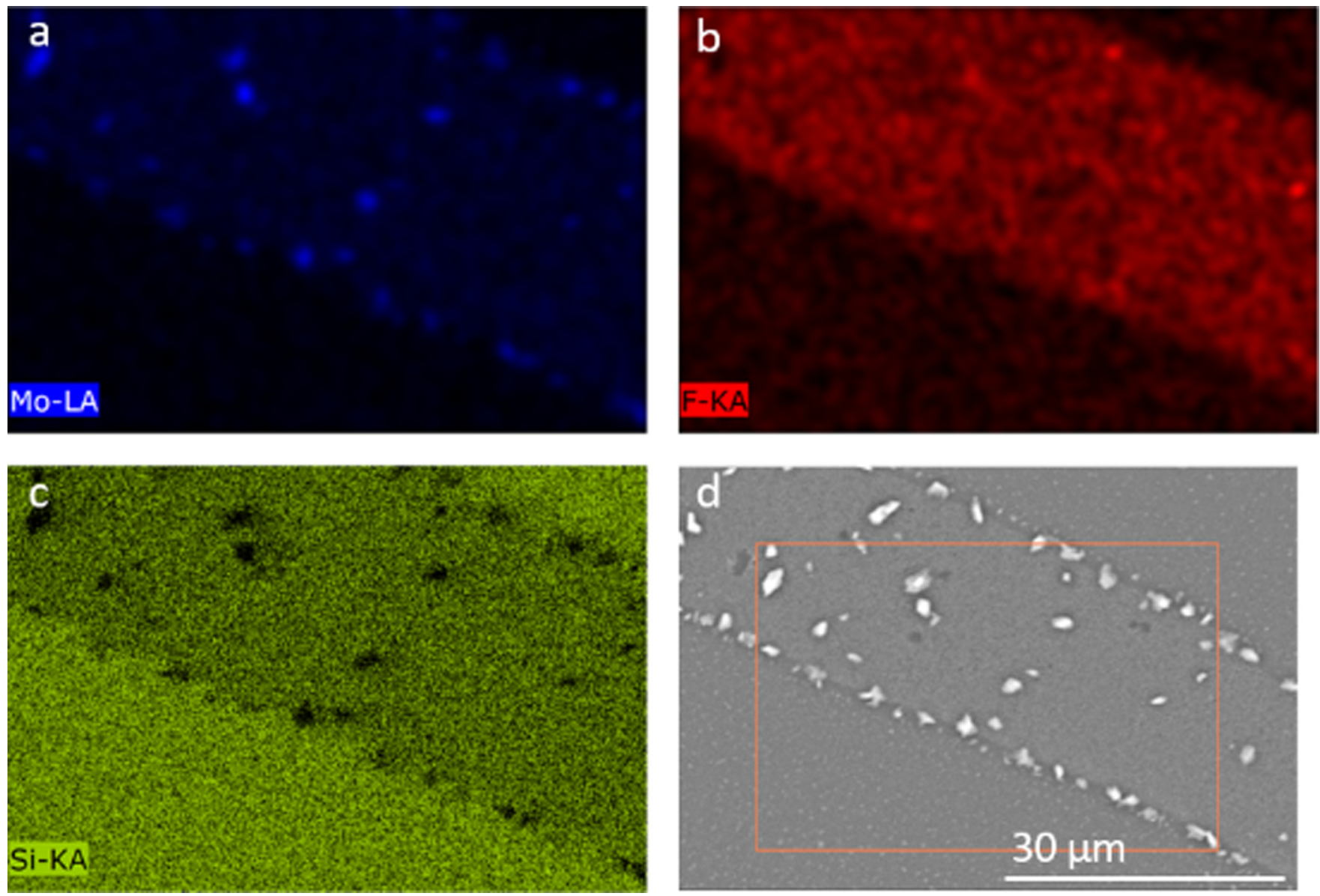

FIG. 10. EDS mapping of molybdenum La (a), fluorine Ka as a measure of LiF (b) and silicon Ka (c) in addition to an SEM micrograph of the surrounding area (d) of an $\mathrm{MoO}_{\mathrm{x}}$ film deposited at $300^{\circ} \mathrm{C}$ on a patterned LiF substrate. The square in subfigure (d) corresponds to the area in which the EDS measurements are performed within. 
the proposed reaction between $\mathrm{H}_{2} \mathrm{O}$ and $\mathrm{MoCl}_{4} \mathrm{O}$,

$$
\mathrm{MoCl}_{4} \mathrm{O}(\mathrm{g})+2 \mathrm{H}_{2} \mathrm{O}(\mathrm{g}) \rightarrow \mathrm{MoO}_{3}(\mathrm{~s})+4 \mathrm{HCl}(\mathrm{g}) .
$$

The calculated equilibrium constant, $\mathrm{K}$, of this reaction is $2.3 \cdot 10^{8}, 8.4 \cdot 10^{7}$, and $3.7 \cdot 10^{7}$ at 200,250 , and $300^{\circ} \mathrm{C}$, respectively. These large values point to a very favorable reaction, which is consistent with our observations. The equilibrium constant decreases one order of magnitude from 200 to $300{ }^{\circ} \mathrm{C}$ but still remain at a very high level. Even though $\mathrm{MoCl}_{4} \mathrm{O}$ is known to thermally and photocatalytically decompose to $\mathrm{MoCl}_{3} \mathrm{O}$ and $\mathrm{Cl}_{2}$ already at room temperature, we still observed $\mathrm{MoCl}_{4} \mathrm{O}$ 's distinct dark green color also after being connected to the ALD reactor in a glass bubbler with inert gas for weeks during deposition campaigns. ${ }^{46}$

A possible reason why $\mathrm{MoCl}_{4} \mathrm{O}$ has not previously been explored as an ALD precursor is the failed attempts to use the tungsten analog, $\mathrm{WCl}_{4} \mathrm{O}$, to deposit $\mathrm{WO}_{3}$. The previous attempts of using $\mathrm{WCl}_{4} \mathrm{O}$ as an $\mathrm{ALD}$ precursor showed no growth on $\mathrm{Si}(100)$, but signs of growth were seen on $\mathrm{La}_{2} \mathrm{O}_{3}$ and $\mathrm{Al}_{2} \mathrm{O}_{3}{ }^{25}$ when $\mathrm{H}_{2} \mathrm{O}$ was used as the oxygen source. Likewise, we did not observe growth on $\mathrm{Si}(100)$, and based on our study, we would anticipate similar reaction schemes for $\mathrm{WCl}_{4} \mathrm{O}$ as we observe for our $\mathrm{MoCl}_{4} \mathrm{O}$, i.e., a selective growth on alkali-containing substrates. A difference between the $\mathrm{WCl}_{4} \mathrm{O}$ and our system is that the $\mathrm{WO}_{3}$ films obtained on $\mathrm{La}_{2} \mathrm{O}_{3}$ and $\mathrm{Al}_{2} \mathrm{O}_{3}$ contained almost as much chlorine as tungsten. However, this may be connected with that $\mathrm{O}_{3}$ was not used together with water in the prior study. Moreover, a very recent work studying ALE of $\mathrm{W}$ utilizes $\mathrm{WCl}_{6}$ in combination with $\mathrm{O}_{2}$ or $\mathrm{O}_{3}$ to form volatile $\mathrm{WCl}_{4} \mathrm{O} / \mathrm{WCl}_{2} \mathrm{O}_{2}$ in order to etch a W surface ${ }^{47}$ and thus the reversed chemistry. Here, thermodynamic modeling reveals that the formation of gaseous $\mathrm{WCl}_{4} \mathrm{O}$ or $\mathrm{WCl}_{2} \mathrm{O}_{2}$ from $\mathrm{WCl}_{6}$ and $\mathrm{WO}_{3}$ is favorable at $\geq 200^{\circ} \mathrm{C}$.

Our study is not the first successful usage of oxychlorides as an ALD precursor. In situ generated $\mathrm{NbOCl}_{3}$ has been reported to deposit $\mathrm{Nb}_{2} \mathrm{O}_{5}$ in combination with water. ${ }^{48}$ This was revealed as the probable reason why $\mathrm{NbCl}_{5}$ and water yielded $\mathrm{Nb}_{2} \mathrm{O}_{5}$ films with large gradients along the flow direction. $\mathrm{NbOCl}_{3}$ was generated from $\mathrm{NbCl}_{5}$ being pulsed into the chamber and reacting with the already present $\mathrm{Nb}_{2} \mathrm{O}_{5}$ film, thus etching the film. Based on our current findings, we expect that $\mathrm{NbOCl}_{3}$ would work as a precursor for deposition of $\mathrm{Nb}_{2} \mathrm{O}_{5}$ also when used directly. A similar etching process as observed for $\mathrm{NbCl}_{5}$ on $\mathrm{Nb}_{2} \mathrm{O}_{5}$ has also been seen for $\mathrm{TaCl}_{5}$ on $\mathrm{Ta}_{2} \mathrm{O}_{5}$ but less thoroughly investigated. ${ }^{49}$

The XRD investigations show that the type of crystalline phases depends on the deposition temperature, ranging from $\mathrm{Mo}_{9} \mathrm{O}_{26}\left(\mathrm{P} \mathrm{2} / \mathrm{c}\right.$ ) at $250{ }^{\circ} \mathrm{C}$ to an XRD amorphous phase at $275^{\circ} \mathrm{C}$ and $\mathrm{MoO}_{2}$ at $300^{\circ} \mathrm{C}$. The average oxidation state of $\mathrm{Mo}$ in $\mathrm{Mo}_{9} \mathrm{O}_{26}$ is $5.8+$, e.g., almost $6+$. XPS studies performed on a sample deposited at $300^{\circ} \mathrm{C}$ shows that $6+$ is the dominant valence of Mo in that sample also. This is in contrast with XRD peaks of $\mathrm{MoO}_{2}$ for the same sample, where the oxidation state for Mo is $4+$. We therefore believe the film mainly consists of an amorphous $\mathrm{MoO}_{3}$ matrix with embedded crystalline $\mathrm{MoO}_{2}$ islands, when deposited at $300^{\circ}$ C. The fact that $\mathrm{MoO}_{2}$ is formed only at high temperatures is consistent with how the equilibrium constant, $\mathrm{K}$, changes as a function of temperature for the reaction in Eq. (3),

$$
\mathrm{MoO}_{3}(\mathrm{~s})+\mathrm{MoCl}_{4} \mathrm{O}(\mathrm{g}) \rightarrow \mathrm{MoO}_{2}(\mathrm{~s})+\mathrm{MoCl}_{2} \mathrm{O}_{2}(\mathrm{~g})+\mathrm{Cl}_{2}(\mathrm{~g})
$$

Here, $\mathrm{K}$ is $6.6 \cdot 10^{-5}, 9.1 \cdot 10^{-4}$, and $7.9 \cdot 10^{-3}$ at 200,250 , and $300{ }^{\circ} \mathrm{C}$, respectively, proving a two order magnitude change with temperature, suggesting why we observe $\mathrm{MoO}_{2}$ only at high temperatures.

The growth rate of our $\mathrm{MoCl}_{4} \mathrm{O}+\left(\mathrm{H}_{2} \mathrm{O}+\mathrm{O}_{3}\right)$ system showed a sudden increase from 0.13 to $0.71 \AA$ /cycle for 1000 cycles when the deposition temperature was increased from 275 to $300^{\circ} \mathrm{C}$. Such a high thermal sensitivity of the growth rate point at a thermally activated process, such as solid-state diffusion, where exponential dependency of diffusion rate with temperature is expected.

An unusual trait of this ALD process is that the growth rate per cycle is not constant as a function of number of cycles, i.e., on the thickness of the deposited film. The growth rate slows down when the number of cycles is increased and the film becomes thicker. This means that we do not enter a typical steady-state ALD situation where the entire surface is saturated and the material deposits on itself, but rather a situation where a longer distance to the interface of the substrate limits the growth.

Studies of growth rates versus purge lengths and a nonlinear relationship between the thickness of the deposited film and number of ALD cycles suggest that the growth is limited by diffusion of $\mathrm{Li}^{+} / \mathrm{Na}^{+}$ions through the film and that the presence of alkali ions is essential for film growth. The fact that soda-lime glass facilitates growth, but silica does not, also supports this. The XPS depth profile of film deposited on glass does show sodium throughout the entire film, proving that diffusion of sodium has taken place. Since $\mathrm{Na}_{2} \mathrm{CO}_{3}, \mathrm{Li}_{3} \mathrm{PO}_{3}$, and $\mathrm{Li}_{2} \mathrm{SiO}_{3}$ coated substrates did not induce film growth, the alkali ion cannot be in any arbitrary matrix. The $\mathrm{Na}_{2} \mathrm{CO}_{3}, \mathrm{Li}_{3} \mathrm{PO}_{3}$, and $\mathrm{Li}_{2} \mathrm{SiO}_{3}$ were all expected to be terminated by a thin carbonate layer on its surface. A possible denominator is if these carbonate layers themselves lack the feature to initiate $\mathrm{MoCl}_{4} \mathrm{O}+\left(\mathrm{O}_{3}+\mathrm{H}_{2} \mathrm{O}\right)$ growth. A more thorough understanding of the growth mechanisms will be a topic for more focused studies.

Also, the SEM micrographs of our thin films deposited on glass and $\mathrm{LiF}$ show a grainier appearance and do not cover the surface in an optimal manner when grown on LiF. This suggests that the nucleation may be more favorable on glass than LiF, despite the near equal measured growth rate.

The selectivity of our system is near perfect for glass over $\mathrm{Si}$ (100) with a native oxide layer. This is to the best of our knowledge also the first report of selective area atomic layer deposition of any molybdenum containing compound. Moreover, it is indeed extreme that the selectivity retained even for as much as 1000 cycles. It is rare that a system exhibits selectivity over so many cycles, as 250 cycles is typically reported as the maximum number of cycles before extra measures, such as etching steps, are required. ${ }^{2}$

Taking the extreme selectivity into account, this work has thoroughly studied the possible $\mathrm{MoO}_{\mathrm{x}}$ growth on $\mathrm{Si}(100)$. As all data from EDS, SEM, and XPS point to the same conclusion, that $\mathrm{MoO}_{\mathrm{x}}$ does not growth on $\mathrm{Si}(100)$ using $\mathrm{MoCl}_{4} \mathrm{O}+\left(\mathrm{O}_{3}+\mathrm{H}_{2} \mathrm{O}\right)$ at temperatures of $300^{\circ} \mathrm{C}$ or less, we have confidence in that the system indeed is perfectly selective within this temperature range. 


\section{SUMMARY AND CONCLUSIONS}

We have reported on the use of the novel precursor $\mathrm{MoCl}_{4} \mathrm{O}$ for deposition of various molybdenum oxides with ALD using deposition temperatures between 200 and $350^{\circ} \mathrm{C}$. The highest growth rate was $0.72 \AA /$ cycle when deposited on soda-lime glass at $300^{\circ} \mathrm{C}$. The $\mathrm{MoCl}_{4} \mathrm{O}+\left(\mathrm{H}_{2} \mathrm{O}+\mathrm{O}_{3}\right)$ process is clearly dependent on the chemistry of the substrate. It shows highly area-selective growth when deposited on substrates containing available lithium or sodium, only growing on glass and $\mathrm{LiF}$ and not on $\mathrm{Li}_{3} \mathrm{PO}_{3}, \mathrm{CaCO}_{3}$, $\mathrm{Na}_{2} \mathrm{CO}_{3}, \mathrm{Si}(100)$ with a native oxide layer, or silica. Moreover, the system is perfectly selective as measured by EDS for glass over $\mathrm{Si}$ (100) with a native oxide layer in the temperature range of 200 $300^{\circ} \mathrm{C}$. XPS analysis showed a large presence of sodium in the film deposited on glass and likewise lithium in the film deposited on $\mathrm{LiF}$. This presence of mobile $\mathrm{Li}^{+} / \mathrm{Na}^{+}$is most likely the key feature of the nucleation and growth and opens for deposition of patterned structures of molybdenum oxides.

\section{ACKNOWLEDGMENTS}

The authors would like to acknowledge the Research Council of Norway for financing this work through the TRALALALA project within the ENERGIX program (No. 244087, Julie Nitsche Kvalvik and Per-Anders Hansen) and the Norwegian Micro- and Nano-Fabrication Facility, NorFab (No. 245963, Jon Borgersen). Furthermore, the authors would like to thank Kristian B. Kvamme, Amund Ruud, and Kjetil Almaas for providing substrates and Kristian Weibye for performing the XPS measurements.

\section{REFERENCES}

${ }^{1}$ B. Wu and A. Kumar, J. Vac. Sci. Technol. B 25, 1743 (2007).

${ }^{2}$ R. Chen, H. Kim, P. C. McIntyre, D. W. Porter, and S. F. Bent, Appl. Phys. Lett. 86, 191910 (2005).

${ }^{3}$ R. Clark, K. Tapily, K.-H. Yu, T. Hakamata, S. Consiglio, D. O’Meara, C. Wajda, J. Smith, and G. Leusink, APL Mater. 6, 058203 (2018).

${ }^{4}$ L. Casagrande, L. Lietti, I. Nova, P. Forzatti, and A. Baiker, Appl. Catal. B 22, 63 (1999).

5. Sonnemans and P. Mars, J. Catal. 31, 209 (1973).

${ }^{6}$ H. Chang, Q. Wu, T. Zhang, M. Li, X. Sun, J. Li, L. Duan, and J. Hao, Environ. Sci. Technol. 49, 12388 (2015).

${ }^{7}$ O. M. Hussain and K. S. Rao, Mater. Chem. Phys. 80, 638 (2003).

${ }^{8}$ M. S. Go, J.-M. Song, C. Kim, J. Lee, J. Kim, and M. J. Lee, Electron. Mater. Lett. 11, 252 (2015)

${ }^{9}$ C. Zollfrank, K. Gutbrod, P. Wechsler, and J. P. Guggenbichler, Mater. Sci. Eng. C 32, 47 (2012)

${ }^{10}$ Y. Liu, Y. Lv, Z. Tang, L. He, and X. Liu, Electrochim. Acta 189, 184 (2016).

${ }^{11}$ U. K. Sen and S. Mitra, RSC Adv. 2, 11123 (2012).

${ }^{12}$ Y. Jin, H. Wang, J. Li, X. Yue, Y. Han, P. K. Shen, and Y. Cui, Adv. Mater. 28, 3785 (2016).

${ }^{13}$ V. Guidi, G. Carlo Cardinali, L. Dori, G. Faglia, M. Ferroni, G. Martinelli,

P. Nelli, and G. Sberveglieri, Sens. Actuators B Chem. 49, 88 (1998).

${ }^{14}$ D. Zhao, J. Qin, L. Zheng, and M. Cao, Chem. Mater. 28, 4180 (2016).

${ }^{15}$ S. K. Deb and J. A. Chopoorian, J. Appl. Phys. 37, 4818 (1966).

${ }^{16}$ P. F. Carcia and E. M. McCarron, Thin Solid Films 155, 53 (1987).
${ }^{17}$ C. Julien, A. Khelfa, O. M. Hussain, and G. A. Nazri, J. Cryst. Growth 156, 235 (1995).

${ }^{18}$ R. M. Guerrero, J. R. V. Garcia, V. Santes, and E. Gomez, J. Alloys Compd. 434, 701 (2007).

${ }^{19}$ M. Diskus, O. Nilsen, and H. Fjellvag, J. Mater. Chem. 21, 705 (2011).

${ }^{20}$ C. E. Nanayakkara, A. Vega, G. Liu, C. L. Dezelah, R. K. Kanjolia, and Y. J. Chabal, Chem. Mater. 28, 8591 (2016).

${ }^{21}$ T. L. Drake and P. C. Stair, J. Vac. Sci. Technol. A 34, 051403 (2016).

${ }^{22}$ T. Jurca, A. W. Peters, A. R. Mouat, O. K. Farha, J. T. Hupp, T. L. Lohr, M. Delferro, and T. J. Marks, Dalton Trans. 46, 1172 (2017).

${ }^{23}$ A. Bertuch, G. Sundaram, M. Saly, D. Moser, and R. Kanjolia, J. Vac. Sci. Technol. A 32, 01A119 (2014).

${ }^{24}$ M. F. J. Vos, B. Macco, N. F. W. Thissen, A. A. Bol, and W. M. M. Kessels, J. Vac. Sci. Technol. A 34, 01 A103 (2016).

${ }^{25}$ K. Bergum, A. Magraso, H. Fjellvag, and O. Nilsen, J. Mater. Chem. A 2, 18463 (2014)

${ }^{26}$ A. J. M. Mackus, A. A. Bol, and W. M. M. Kessels, Nanoscale 6, 10941 (2014).

${ }^{27}$ G. N. Parsons, J. Vac. Sci. Technol. A 37, 020911 (2019).

${ }^{28}$ J. A. Singh, N. F. W. Thissen, W.-H. Kim, H. Johnson, W. M. M. Kessels, A. A. Bol, S. F. Bent, and A. J. M. Mackus, Chem. Mater. 30, 663 (2018)

${ }^{29}$ A. Mameli, M. J. M. Merkx, B. Karasulu, F. Roozeboom, W. M. M. Kessels, and A. J. M. Mackus, ACS Nano 11, 9303 (2017).

${ }^{30}$ E. K. Seo, J. W. Lee, H. M. Sung-Suh, and M. M. Sung, Chem. Mater. 16, 1878 (2004).

${ }^{31}$ I. Zyulkov, V. Madhiwala, E. Voronina, M. Snelgrove, J. Bogan, R. O'Connor, S. De Gendt, and S. Armini, ACS Appl. Mater. Interfaces 12, 4678 (2020).

${ }^{32}$ Z. Zhang, T. Dwyer, S. M. Sirard, and J. G. Ekerdt, J. Vac. Sci. Technol. A 37, 020905 (2019).

${ }^{33}$ F. S. Minaye Hashemi, C. Prasittichai, and S. F. Bent, ACS Nano 9, 8710 (2015).

${ }^{34}$ J. N. Kvalvik, K. B. Kvamme, K. Almaas, A. Ruud, H. H. Sønsteby, and O. Nilsen, "LiF by atomic layer deposition - made easy," J. Vac. Sci. Technol. A (submitted).

${ }^{35}$ O. Nilsen, H. Fjellvåg, and A. Kjekshus, Thin Solid Films 450, 240 (2004).

${ }^{36} \varnothing$. S. Fjellvåg, Tynne filmer og nanobelter for batterier: Syntese og karakterisering av katodematerialer for litium-og natriumionbatterier (University of Oslo, Oslo, Norway, 2014).

${ }^{37}$ A. Ruud, V. Miikkulainen, K. Mizohata, H. Fjellvåg, and O. Nilsen, J. Vac. Sci. Technol. A 35, $01 \mathrm{~B} 133$ (2017).

${ }^{38}$ A. Magneli, Acta Cryst. 6, 495 (1953).

${ }^{39}$ O. Bertrand, P. Dufour, N. Floquet, and L. C. Dufoue, Phys. Status Solidi A 71, $511(1982)$

${ }^{40}$ M. Diskus, O. Nilsen, H. Fjellvåg, S. Diplas, P. Beato, C. Harvey, E. Lantman, and B. Weckhuysen, J. Vac. Sci. Technol. A 30, 01 A107 (2012).

${ }^{41} \emptyset$. S. Fjellvåg, A. Ruud, H. H. Sønsteby, O. Nilsen, and H. Fjellvåg, Cryst. Growth Des. 20, 3861-3866 (2020).

${ }^{42}$ H. Gruber and E. Krautz, Phys. Satus Solidi A 62, 615 (1980).

${ }^{43}$ T. Leisegang, A. A. Levin, J. Walter, and D. C. Meyer, Cryst. Res. Technol. 40, 95 (2005).

${ }^{44}$ J. G. Choi and L. T. Thompson, Appl. Surf. Sci. 93, 143 (1996).

${ }^{45}$ A. Fick, Ann. Phys. 170, 59 (1855).

46“Tungsten and molybdenum tetrachloride oxides," in Inorganic Syntheses (John Wiley \& Sons, Inc., New York, 1980), pp. 195-199.

${ }^{47}$ W. Xie and G. N. Parsons, J. Vac. Sci. Technol. A 38, 022605 (2020).

${ }^{48}$ K. Knapas, A. Rahtu, and M. Ritala, Chem. Vap. Depos. 15, 269 (2009).

${ }^{49}$ J. Aarik, A. Aidla, K. Kukli, and T. Uustare, J. Cryst. Growth 144, 116 (1994).

${ }^{50}$ See supplementary material at http://dx.doi.org/10.1116/6.0000219 for (1) measured film thicknesses before and after deposition of $\mathrm{MoO}_{\mathrm{x}}$ at $300{ }^{\circ} \mathrm{C}$, (2) measured at.\% from EDS used for selectivity calculations and (3) modelling of thickness vs number of cycles. 